\title{
Environmental performance of rainwater harvesting strategies in Mediterranean buildings
}

Sara Angrill ${ }^{a}$, Luis Segura-Castillo ${ }^{b, c}$, Anna Petit-Boix ${ }^{a, *}$, Joan Rieradevall $^{a, d}$, Xavier Gabarrell $^{a, d}$, Alejandro Josa ${ }^{e, f}$

${ }^{a}$ Sostenipra (ICTA-IRTA-Inèdit; 2014 SGR 1412) Institute of Environmental Science and Technology (ICTA; Unidad de excelencia «María de Maeztu» (MDM-2015-0552)), Universitat Autònoma de Barcelona (UAB), Edifici ICTAICP, Carrer de les Columnes, 08193 Bellaterra, Barcelona, Spain.

${ }^{b}$ Department of Civil and Environmental Engineering, Structures, Materials and Construction Technology Division, School of Civil Engineering (ETSECCPB), Technical University of Catalonia - Barcelona Tech (UPC, Campus Nord), C/ Jordi Girona 1-3, Building C1, 08034 Barcelona, Spain.

${ }^{c}$ Institute of Structures and Transport (IET), Faculty of Engineering, University of the Republic (UdelaR). J. Herrera y Reissig 565-11300 Montevideo, Uruguay

${ }^{d}$ Department of Chemical, Biological and Environmental Engineering, Biotechnology Network Reference (XRB), School of Engineering (EE), Universitat Autònoma de Barcelona (UAB), Campus Bellaterra, Cerdanyola del Vallès, 08193 Barcelona, Spain.

${ }^{e}$ Department of Civil and Environmental Engineering, Geotechnical Engineering Division, School of Civil Engineering, Universitat Politècnica de Catalunya (UPC-BarcelonaTech), Jordi Girona 1-3, Building D2, Barcelona, Spain.

${ }_{\mathrm{f}}^{\mathrm{f}}$ Institute of Sustainability (IS.UPC), Universitat Politècnica de Catalunya (UPC-BarcelonaTech), Jordi Girona 31, Barcelona, Spain

\footnotetext{
* Corresponding Author

Email: anna.petit@uab.cat Postal address: Sostenipra (ICTA-IRTA-Inèdit; 2014 SGR 1412) Institute of Environmental Science and Technology (ICTA; Unidad de excelencia «María de Maeztu»(MDM-2015-0552)), Universitat Autònoma de Barcelona (UAB), Edifici ICTA-ICP, Carrer de les Columnes, 08193 Bellaterra, Barcelona, Spain; Phone number: (+34) 935868644

Post-print of Angrill, Sara et al. «Environmental performance of rainwater
harvesting strategies in Mediterranean buildings» in The international journal of
life cycle assessment (Springer), Vol. 22, Issue 3 (March 2017), p. 398-409. The
final version is available at DOI 10.1007/s11367-016-1174-x
}




\begin{abstract}
Purpose: The rapid urbanization and the constant expansion of urban areas during the last decades have locally led to increasing water shortage. Rainwater harvesting (RWH) systems have the potential to be an important contributor to urban water self-sufficiency. The goal of this study was to select an environmentally optimal RWH strategy in newly constructed residential buildings linked to rainwater demand for laundry under Mediterranean climatic conditions, without accounting for water from the mains.
\end{abstract}

Methods: Different strategies were environmentally assessed for the design and use of rainwater harvesting (RWH) infrastructures in residential apartment blocks in Mediterranean climates. The harvested rainwater was used for laundry in all strategies. These strategies accounted for: (i) tank location (i.e., tank distributed over the roof and underground tank); (ii) building height considering the number of stories (i.e., 6, 9, 12 and 15); (iii) distribution strategy (i.e., shared laundry, supply to the nearest apartments and distribution throughout the building). The RWH systems consisted of the catchment, storage and distribution stages and the structural and hydraulic calculations were based on Mediterranean conditions. The quantification of the environmental performance of each strategy (e.g., $\mathrm{CO}_{2}$ eq. emissions) was performed in accordance with the Life Cycle Assessment methodology.

Results and discussion: According to the environmental assessment, the tank location and distribution strategy chosen were the most important variables in the optimization of RWH systems. Roof tank strategies present fewer impacts than their underground tank equivalents because they enhance energy and material savings, and their reinforcement requirements can be accounted for within the safety factors of the building structure without the tank. Among roof tanks and depending on the height, a distribution strategy that concentrates demand in a laundry room was the preferable option, resulting in reductions from $25 \%$ to $54 \%$ in most of the selected impact categories compared to distribution throughout the building.

Conclusions: These results may set new urban planning standards for the design and construction of buildings from the perspective of sustainable water management. In this sense, a behavioral change regarding demand should be promoted in compact, dense urban settlements.

Keywords: Sustainable buildings, Water management, Laundry demand, Urban planning, LCA, Environmental impact. 


\section{Introduction}

\subsection{Rainwater harvesting in urban areas}

The rapid urbanization and the constant expansion of urban areas during the last decades have led to increasing water shortages. This situation is being aggravated in water-stressed climates, such as the Mediterranean, which present high risks for droughts as well as sudden and intense rainfall events that result in flooding (Ngigi 2003). Rainwater harvesting (RWH) has been utilized for centuries to fulfill household and agricultural requirements (Pandey et al. 2003). It consists of collecting rainwater, coming mostly from rooftops or impervious areas, storing in a tank with varying locations (e.g., on the roof, underground, etc.) and distributing to specific non-potable end-uses. Although untreated harvested rainwater is often unsuitable for drinking due to the presence of microbes and pathogens (Zhu et al. 2004; Sazakli et al. 2007), numerous studies guarantee rainwater quality for toilet flushing, laundry and gardening irrigation (Lye 2009).

RWH is currently increasingly implemented in areas with very different rainfall patterns, such as Jordan (Abdulla and Al-Shareef 2009), India (Glendenning and Vervoort 2011), South Africa (Mwenge Kahinda and Taigbenu 2011), Brazil (Ghisi et al. 2007), the United States (USA) (Jones and Hunt 2010), Australia (Zhang et al. 2009), China (PUB 2012) and the United Kingdom (UK) (Roebuck et al. 2010). The main benefits associated with RWH include flood risk reduction, self-sufficiency and decreased dependency on distant water sources, reduction of stormwater flows treated in wastewater treatment plants, and reduction of non-point water pollution (Coombes et al. 2002; Villarreal and Dixon 2005; van Roon 2007; Fletcher et al. 2008; Zhang et al. 2009; Rahman et al. 2010).

\subsection{RWH strategies in urban areas: Scale and tank location}

Trends in urban morphology are converging on more compact cities, where population density and building height play a significant role (Oliver-Solà et al. 2011). In this context, RWH systems have the potential to be an important contributor to urban water self-sufficiency. Until now, the parameters selected to design RWH infrastructures and to determine their potential have been the catchment area, rainfall pattern, degree of roof slope, runoff coefficient (RC) and roof materials (Farreny et al. 2011b). Housing type and density also affect the efficiency of the RWH system, as do occupancy and non-potable demand (Devkota et al. 2015b). The installation of decentralized technologies in multifamily buildings may be favored by economies of scale and cost sharing arrangements (Nolde 2007). The collection efficiency is also larger in high-density urban areas because the water consumption pattern per hectare is greater and, 
therefore, all water collected is more likely to be consumed (Herrmann and Schmida 2000). However, the percentage of demand met is usually lower than in low density neighborhoods because the latter usually present larger catchment surfaces per dwelling and, therefore, per consumer. From this point of view, several studies on RWH applied to multifamily buildings were performed in Sweden (Villarreal and Dixon 2005), Malta (Reitano 2011), Germany (Herrmann and Schmida 2000) and UK (Ward et al. 2010), to cite just a few.

The relevance of the tank location as a criterion for the design of RWH infrastructures was previously examined together with urban density (Angrill et al. 2012). For diffuse and compact urban areas in the Mediterranean climate, tanks located over flat roofs in newly constructed buildings were the most favored option from an environmental standpoint. That was due to the equal distribution of the weight of the tank along the building structure and the possibility of a gravitational distribution of rainwater, thus avoiding the need for pumping, which leads to comparably low additional construction demands. Similarly, an exergy or useful-energy analysis concluded that a tank distributed over the roof of buildings with a relatively high density is the most efficient option (Vargas-Parra et al. 2013). However, underground or external tank locations are currently the most frequently implemented strategies, possibly due to aesthetics or accessibility. Another factor that may influence the performance of RWH systems from an environmental, social and economic point of view is the demand distribution within the building (Domènech and Saurí 2011). When the demand is specifically located close to the tank, there might be lower construction requirements and elements, but this assertion has yet to be analyzed.

\subsection{Precedents for the assessment of environmental impacts of RWH systems}

Until now, there is a lack of research on the environmental performance of RWH systems, in particular for multistory residential buildings. Proper planning of the water supply infrastructure should consider the implications of the material, energy and emissions resulting from this system, as well as water-related issues. Hence, it requires a Life Cycle Assessment (LCA) approach, where the impacts of these infrastructures are holistically evaluated through the entire life cycle (Stokes and Horvath 2006). In the literature, few studies use LCA tools to determine the critical points of the urban water cycle (Herz and Lipkow 2002; Lundie et al. 2004; Lassaux et al. 2007; Venkatesh et al. 2009) and even fewer assess the installation of RWH in urban environments (Morales-Pinzón et al. 2012a; Devkota et al. 2015a). Most of these analyses focus on particular stages and components of the RWH system's life cycle (Bronchi and Jolliet 2002; Grant and Hallmann 2003). 
This research aimed to identify additional criteria for sustainable RWH systems from an environmental standpoint and intended to provide sustainability guidelines for urban planners in the design of newly constructed neighborhoods with different population densities. To fulfill future demands, water policies should focus on an integrated water management, increasing the range of supply alternatives and acting upon demand (Saurí 2003). In this sense, which is the best water demand distribution in a building that benefits from RWH at the lowest environmental cost? The goal of this research was to select an environmentally optimal RWH strategy in newly constructed residential buildings linked to a constant water demand for laundry under Mediterranean climatic conditions. Two tank locations were analyzed: a tank distributed over the roof and an underground tank. For both locations, three different water distribution alternatives were proposed (i.e., supply to the nearest apartments, shared laundry room and distribution to all the apartments in the building). At the same time, four building heights were set $(6,9,12$ and 15 floors) to determine the contribution of the height of the building to the impact of RWH systems.

\section{Scope Definition and Methodology}

In this section, the system under analysis is defined (Section 2.1-2.2). The structural parameters considered are presented in Section 2.3, and Section 2.4 deals with the environmental calculation tools.

\subsection{Functional unit (FU)}

An LCA approach was used to assess the environmental impacts related to the RWH infrastructures of 24 scenarios with varying tank location, building height and demand distribution (Section 2.2). The FU was defined as the catchment, storage, and supply of $1 \mathrm{~m}^{3}$ of rainwater per building per year to be used as non-potable water for a constant demand for laundry and with varying user behavior and habits. This definition takes into account the catchment area per building, the available water to be supplied and the annual water demand per dwelling under Mediterranean climatic conditions. In this study, we compared different scenarios for supplying water for laundry to different apartment buildings, but a baseline scenario for conventional water supply (i.e., water from the mains) was not included.

\subsection{Description of the system under study}

\subsubsection{Reference flows}


Rainfall: An average annual rainfall of $620 \mathrm{~mm}$ was considered for Barcelona (Spain), according to data collected by AEMET (2013) during the last twenty years. This amount was considered representative of the Mediterranean climate for which the average rainfall varies within a range between 600 and $750 \mathrm{~mm}$ per year. This climate is characteristic of several regions in the world such as California, southern Chile, Cape Province in South Africa, the Mediterranean basin and the south-southwest of Australia (di Castri and Mooney 1973). To assess the effects of climate, the rainwater demand met in Barcelona was compared with that of other Spanish cities with different precipitation patterns, i.e., Madrid $(420 \mathrm{~mm})$, Murcia $(270 \mathrm{~mm})$ and Santiago de Compostela $(1750 \mathrm{~mm})$. For modeling, daily rainfall data for the last twenty years were used (AEMET 2013).

Water demand: The use of rainwater for laundry is one of the most common practices for non-potable water, together with irrigation and toilet flushing (Leggett et al. 2001); laundry represents $20 \%$ of the domestic demand in a standard dwelling (Elzen et al. 2004). The average weekly consumption in European households is set at 300 L per week (assuming four wash loads per week) based on the eco-efficiency parameters required for the acquisition of the A+ ecolabel for washing machines (Commission Regulation 2010). The annual demand for laundry was set at $15.5 \mathrm{~m}^{3}$ per dwelling. The designed RWH infrastructure was intended to supply the maximum possible demand considering the average rainfall and its frequency.

\subsubsection{Building characteristics}

The building design consisted of a newly constructed residential building with $690 \mathrm{~m}^{2}$ of floor area (additional structural data are given in Online Resource 1). The selection of this wide floor area facilitates different building heights to fit this structure without being out of proportion. For this floor area, a ' $U$ ' shape was chosen because it enables widening the surface of the façade in relation to the floor area. Moreover, it allowed the underground tank to be placed beside the building foundation (on the inside face of the $\mathrm{U}$ ). This shape is widely common in buildings since it can be found in many architectural collections and was also summarized by Meng and Forberg (2007). Every floor was distributed into six apartments that were given $100 \mathrm{~m}^{2}$ of floor area each. The first floor, or ground floor, was not considered as habitable but was intended for commercial or other activities.

\subsubsection{Definition of scenarios}


According to the results obtained in previous studies (Angrill et al. 2012), two different tank locations were chosen: a tank distributed over the roof $(\mathrm{R})$ and an underground tank $(\mathrm{U})$. By doing so, the best tank location was determined under different demand distribution strategies and building heights. To examine the influence of building height and compare medium and very high-density buildings, four construction heights with a constant floor area $\left(690 \mathrm{~m}^{2}\right)$ were proposed: a six-story building (30 apartments), a nine-story building (48 apartments), a twelve-story building (66 apartments) and a fifteen-story building (84 apartments).

For each tank location ( $\mathrm{R}$ and $\mathrm{U})$, three possible distributions of the demand were selected within the building: a community laundry room located on the ground floor (A), concentration of the demand in the stories located near the tank (B), and distribution to all the apartments in the building (C). Laundry rooms are common in the service sector (e.g. university dormitories, hotels and other kind of shared facilities) (Riesenberger and Koeller 2005). In contrast, in residential buildings most dwellings have their own washing machine (Elzen et al. 2004). An alternative distribution (strategy B) that stands between strategies A and C takes into account the position of the tank and the rainwater supply and demand. This water distribution strategy concentrates the demand on the upper floors (i.e., upper apartments) in the R scenarios and on the lower floors in the U scenarios (Figure 1), considering the distribution to a fixed number of floors, set at four in all cases.

\section{Fig1}

\subsubsection{Description of the RWH systems}

The most relevant structural data used in the inventory is presented in Table 1. Regarding the catchment stage, it was considered that rainwater is only harvested from flat roofs. Therefore, standard galvanized-steel gutters and polypropylene (PP) downpipes were necessary in the $\mathrm{U}$ scenarios to conduct water from the roof to the tank. In the $\mathrm{R}$ scenarios, water that infiltrates through the roof pavement tiles was collected and stored directly in the tank; hence, the catchment and storage stages coincide (Table 1). It was assumed that $90 \%$ of the total rainfall incident on the roof would enter the tank, given that the initial abstraction of the tiles was considered to be very low (i.e., roof-RC was estimated at 0.9) (Farreny et al. 2011b).

\section{Table 1}


The rainwater tank is the main component of the storage stage, the shape and measures of which vary depending on its location in the building. However, its volume remained constant for all scenarios within this study (Table 1). While the underground tank was intended to be located at the inside face of the ' $U$ ' shape of the building, the roof tank covered the entire extension of the roof. The concrete used in the tank construction and the structural reinforcement of the building had a compressive strength of $30 \mathrm{MPa}$. This reinforcement consisted of the extra structural material required in the building to withstand the weight of the tank and the weight of the water volume and was therefore necessary in the R scenarios. Steel ( $80 \%$ recycled, yield strength of $500 \mathrm{MPa}$ ) was also considered in the construction of the tank (underground tank) and the reinforcement (roof tank).

The distribution stage consisted of polypropylene pipes (PP-copolymer) that conduct water from the tank to a laundry room (distribution strategy A), to the nearest apartments to the tank (B) or to each home laundry (C) for its end-use. Therefore, the pipe length varied depending on the distribution strategy and the number of floors in the building. The $\mathrm{U}$ scenarios required a stainless-steel pump to supply rainwater to each dwelling and it was previously selected and optimized for each distribution strategy and building height. The power consumption over the lifespan of the system was calculated based on 6 minutes of pumping per wash load. In R strategies, it was assumed that the distribution system would have enough pressure to supply water to a washing machine by gravity.

The potential rainwater harvested was the same for all scenarios because the roof area and annual rainfall remained constant, and was estimated to be $385 \mathrm{~m}^{3} / \mathrm{year}$. However, the storage volume was optimized and considered constant $\left(25 \mathrm{~m}^{3}\right)$ for all case studies because an increase in capacity did not represent significant gains in water collection, as identified when modeling the system using Plugrisost v1.0 (Morales-Pinzón et al. 2012b). This software models the tank volume through a continuous daily water balance of supply and demand along the year according to a 90-year rainfall series. Due to the rainfall variability, there will always be tank overflows in certain rainfall events throughout the year and the theoretical maximum will never be reached.

Additionally, water demand increased with the number of floors in the building for distribution strategies A and C. This promoted a more efficient performance of the water storage tank by collecting more water during rain peaks, which are very typical in Mediterranean climates due to the seasonality of the climate and the frequency and intensity of the rainfalls (for further details see Online Resource 2). In this case, the percentage of demand satisfied decreased with the building height, but the absolute volume of rainwater supplied was larger (Table 1). Considering a constant 
tank volume, supplying rainwater to higher buildings appeared to provide a more efficient use of the tank because more rainwater was consumed. In distribution strategy B, water demand was constant for all building heights because rainwater was delivered to a fixed number of floors (Table 1). For this reason, the total water supplied per year was constant and limited by the number of apartments.

\subsection{Structural calculations}

The roof tank was distributed over $633 \mathrm{~m}^{2}$ of roof area (92\% of the total roof) and had a depth of $4 \mathrm{~cm}$, while the underground tank ( $5 \mathrm{~m} \times 3 \mathrm{~m} \times 1.7 \mathrm{~m})$ had a rectangular base. Both tanks were equipped with an overflow system that released rainwater directly into the sewer pipes when the tank was full. A minimum water level was always expected to be present in the tank (either rainwater or, alternatively, water from the mains). A tank top-up system facilitated a dual supply of water by means of a valve for both tank locations.

Data regarding materials and the sizing of the infrastructures were obtained using the structural calculation software CYPE v.2011 (CYPE 2011). Note that the assumptions of the structural analysis (type of soil, criteria for reinforcement, etc.) can significantly affect the result (e.g., the foundation type or the materials used). To reduce this

effect, a sandy soil with a high strength was selected, and the reinforcement was designed to optimize the amount of materials (minimizing the steel in the structure, maintaining the layout of the floors and the concrete in the foundation to keep the underlying stress). Additional data are provided in Online Resource 1.

The lifespan of the rainwater storage tank was set at 50 years (Roebuck et al. 2010), and it was mainly limited by the evolution of technologies and changes in functionality over time. The uptake and distribution pipes and submersible pump were considered to have a useful life of 25 and 15 years, respectively.

\subsection{Environmental life cycle assessment}

The LCA methodology assesses the environmental impacts related to a product, process or activity through the quantification and estimation of the resources consumed and the emissions produced from "cradle to grave". It consists of four main steps: goal and scope definition, inventory analysis, impact assessment and interpretation (ISO 2006).

The inventory considers resources and emissions for all materials and processes along the life-cycle of the infrastructure. The phases considered in the inventory were materials procurement, transportation, construction, use 
and deconstruction for the catchment, storage and distribution systems. The materials stage comprised the extraction, transport, production, processing and storage of materials used in the RWH infrastructure. Background data on the life cycle of materials and energy were retrieved from the ecoinvent database 2.2 (Frischknecht et al. 2005). In the construction stage, the energy flows included land excavation and the opening and closing of trenches. However, for the $\mathrm{R}$ scenarios, the use of machinery in the construction and deconstruction of the catchment and distribution stages was neglected because it was considered to fall within the purview of the building structure. Transport included both local material transportation to the building site and waste transport to a local disposal facility. The use stage consisted of the power demand (Spanish mix) in the distribution stage for those scenarios with pumping requirements (U). The maintenance was excluded, given that the impacts of cleaning activities in sewers were usually found to be low with respect to the electricity consumption (Petit-Boix et al. 2015), and sewers normally accumulate more sludge than RWH systems. The end of life of materials was considered outside the boundaries of the system because there is uncertainty regarding the technological development of recycling in 50 years time. The database Metabase ITeC (2010) provided operational energy consumption information linked to the construction and deconstruction stages.

In the life cycle impact assessment, only the classification and characterization stages were considered. The results were evaluated at the midpoint level for the selected impact categories and characterization factors suggested by CML IA (Guinée et al. 2002), linked to the software SimaPro 7 (PRé Consultants 2010). In this study, the impact categories selected were Abiotic Depletion Potential (ADP, kg Sb eq.), Acidification Potential (AP, kg SO 2 eq.), Eutrophication Potential (EP, $\mathrm{kg} \mathrm{PO}_{4}{ }^{3-}$ eq.), Global Warming Potential (GWP, $\mathrm{kg} \mathrm{CO}_{2}$ eq.), Human Toxicity Potential (HTP, kg 1.4DB eq.), Ozone Depletion Potential (ODP, kg CFC-11 eq.) and Photochemical Ozone Creation Potential (POCP, kg $\mathrm{C}_{2} \mathrm{H}_{4}$ eq.). Most of them are the indicators suggested by EN 15804:2011 for the environmental declaration of construction works, together with the Cumulative Energy Demand (CED, MJ) (Hischier et al. 2010), which was also included in the study for assessing energy issues. To this end, no water indicators were included in the assessment of these constructive elements. HTP is not included in EN 15804:2011, but it was also assessed because it was considered in previous studies dealing with the construction of water-related infrastructures (Angrill et al. 2012; Lemos et al. 2013; Petit-Boix et al. 2014; Petit-Boix et al. 2016).

\section{Results and discussion}

\subsection{Inventory data}


The inventory data take into account the amount of materials and energy required in each scenario for the FU defined and the lifespan of each component. These data were grouped into life cycle stages (materials, transportation, construction, use and deconstruction) and RWH systems (catchment, storage and distribution). The detailed inventory is given in Online Resource 3.

The largest amounts of materials were linked to the storage system for both underground (U) and roof (U) tank scenarios. In the U strategies, the concrete required to build the tank represented $97 \%$ of the total of this stage. For the $\mathrm{R}$ scenarios, the brick and waterproof sheet contributed between $44 \%$ and $66 \%$ to this system, depending on the building height. The concrete requirements linked to the reinforcement of the building accounted for $26 \%-49 \%$ of the total amount of the storage. This reinforcing amount refers to the extra concrete required in the foundations to support the weight of the tank and the water stored, while the steel required in the reinforcement is located mostly in the building structure (71\%-100\%, increasing with building height) and partly in the foundations. However, in the foundations, the steel and concrete reinforcement requirements did not increase linearly with the building height. For this reason, the fifteen-story building required a proportionally smaller amount of reinforcing materials than the twelve-story building. In any case, it can be considered that the structural increase required to locate a roof tank is negligible when compared with the building structure itself because this difference accounts for less than $0.5 \%$ of the total materials required in the construction of the building. In overall, the material requirements of $U$ scenarios ranged from 3.4 to 5.7 times the total amount of material needed in $\mathrm{R}$ scenarios, depending on the building height and the distribution strategy chosen.

\subsection{Environmental assessment of RWH systems}

The outcome of the environmental assessments of underground (U) and roof (R) tank scenarios is first presented separately, combining the different building heights and distribution strategies (Figures 2 and 3). Subsequently, the environmental performance of the best case underground tank scenario (AU) is compared with the worst roof tank strategy (CR) for each impact category (Figure 4). The contribution of each RWH system for each possible scenario is presented in Table 2, taking the GWP category as a reference.

\subsubsection{Impact assessment of underground tanks (U)}

Fig2 
For the U scenarios, the results showed that the distribution strategy A (laundry room placed on the ground floor near the tank) was the best across all impact categories. It was followed by the supply to the stories located near the tank (strategy B), which showed a remarkable difference from the distribution to all the apartments in the building (C) (Figure 2) that becomes greater when there are more stories in the building. Examples of extreme differences between strategies B and C occurred in fifteen-story buildings, where B scored $74 \%$ better than C in the AP indicator, while in PCOP there was a $36 \%$ difference. This outcome was related to the use stage and the energy consumption of the distribution strategy, being more and more energy-demanding and requiring more powerful pumps with increasing building height (Angrill et al. 2012). Distribution strategies A and B showed the same trend with differences between them and the building height remaining quite constant. However, in B strategies the impacts were between $32 \%$ and $48 \%$ greater than in A strategies depending on the impact category, which was mainly associated with the varying water demand in each type of building and distribution strategy.

\subsubsection{Impact assessment of roof tanks $(\mathbf{R})$}

\section{Fig3}


The results showed that in all cases the most environmentally friendly strategy was the laundry room on the ground floor (A), while strategies B and C presented different trends depending on the impact category chosen (Figure 3).

Strategy $\mathrm{C}$ showed a growing tendency correlative with the number of floors due to a greater need for materials. However, the most impacting scenario was not always the fifteen-story building, but rather the twelve-story building for EP, ODP, HTP and POCP. The same trend was observed for the B-strategy scenarios in all impact categories analyzed (Figure 3). This was due to the behavior of the building reinforcement. The reinforcement required to support the weight of the tank affected the upper building structure and the foundations, but these two locations had different performances when more floors are added to the building. The upper structure requires more strengthening (more steel is added) when the building becomes taller, following a linear growth pattern. In contrast, the reinforcement requirements of the foundations were directly related to the tank area, which remained constant with the building height; therefore, the added amount of reinforcement (mainly concrete) was smaller when the number of floors increased. Hence, from the twelve-story building on, less reinforcing steel and concrete were required to support the weight of the tank, according to the design parameters and building standards included in CYPE (2011). In relative terms, this means that the difference of material required was smaller for the fifteen-story building compared to the requirements of the twelve-story building.

Moreover, unlike in the $\mathrm{U}$ scenarios, strategy B performed environmentally worse than strategy C for the six- and nine-story building scenarios (except for ADP and CED) and in three out of seven impact categories (EP, ODP and HTP) for the twelve-story building, with differences that ranged from $1 \%$ to $13 \%$. These results were due to the nature of the water supply and demand, which remained constant with the building height for B strategies and always supplied to a fixed number of apartments. Thus, the use of rainwater was less efficient because more rainwater was disposed of. In contrast, in the $\mathrm{C}$ strategies, the amount of water available per building increased in line with the building height and resulted in lower relative impacts when compared to the B strategies. In this case, the contribution of the storage stage to the total impacts compensated the need for more pipes (Table 2). However, in absolute terms the differences were not significant compared to the underground tank impact results.

\subsubsection{Comparison of roof and underground tank scenarios}

Figure 4 represents the environmental performance of the best U scenario, based on a centralized laundry (AU), compared with the worst R scenario, with a distribution to all apartments in the building (CR), presented for each 
impact category. The absolute values for CR were generally better than the best AU option. The greatest difference was found in ODP and HTP, where CR displayed 66\% lower impacts than AU. However, CR had a negative performance in ADP and CED. In the case of ADP, the waterproof sheet installed at the base of the roof tank to avoid infiltration and the PP distribution pipes, which increases in amount with building height to supply water to all the apartments (strategy C), had the most significant contribution (accounting for up to $91 \%$ of the total in most indicators). A similar converging trend was observed for the GWP and POCP.

\section{Fig4}

Absolute results indicated that, in general, the $\mathrm{U}$ scenarios presented greater impacts than their $\mathrm{R}$ equivalents in all impact categories. This was especially notable in distribution strategy $\mathrm{C}$ because, for underground tanks, the impacts increased following a polynomial trend related to the number of floors in the building. This increase was associated with the pumping energy consumption for the 50 years span of the infrastructure, which was not required in $\mathrm{R}$ scenarios where water had a gravitational flow. Distributing water to a laundry room (A) was the most environmentally efficient option and was most likely the most cost-efficient option as well. The planning and implementation of RWH infrastructures should therefore take into account a proper collective demand management of the building in compactdensity urban settlements.

\subsubsection{Contribution of the life-cycle stages}

The GWP impact category was chosen because of its current importance in climate change in exemplifying the contribution of each life-cycle stage of the RWH infrastructure. Nevertheless, all impact categories analyzed generally showed similar trends.

\section{Table 2}

For the R scenarios, the storage system was the main contributor to the GWP impacts of RWH infrastructures in all building heights due to the reinforcement required to withstand the weight of the tank and the water (Angrill et al. 2012). The relevance of the storage stage decreased with a distribution strategy focused on the nearest floors (B) ( $81 \%$ contributor to the impact compared to $95 \%$ in A). The distribution stage became even more relevant in strategy $\mathrm{C}$, for which the storage loads account for $54 \%$ to $76 \%$, depending on the number of floors in the building. This fact was due to the progressive importance of PP distribution pipes in strategy $\mathrm{C}$ for taller building heights and the lesser importance 
of the reinforcement, which does not grow linearly with the number of floors. Indeed, it can be concluded that building height was not relevant to reinforcement requirements because these can be accounted for within the safety factors of the building structure without the tank; therefore, they are negligible compared to the whole building. Therefore, it is not necessary to consider depreciation in the new construction for the roof tank scenarios because it can be considered to be within the payback period of the building (Farreny et al. 2011a). For the U scenarios, the distribution strategy was the main contributor in scenarios where rainwater was supplied to all the apartments in the building (C). There were differences of magnitude by building height (accounting for $45 \%$ to $81 \%$ of the total), a fact strongly related to the pumping energy requirements associated with the whole lifespan of the infrastructure to deliver rainwater to taller buildings (Angrill et al. 2012).

The absolute values for the GWP category highlighted that the U scenarios were less preferable in environmental terms when compared to the R strategies. The roof tank scenarios reduced their impact between $33 \%$ and $42 \%$ in the A distribution strategies, depending on the building height considered, from $42 \%$ to $48 \%$ in the B strategies and even more in the $\mathrm{C}$ strategies (decreasing from $51 \%$ to $76 \%$ ) (Table 2). We can conclude that the R scenarios would have the lowest impact, being a centralized laundry room (A) always preferable.

\subsection{Regional-scale effects on RWH}

Rainfall patterns affect the design of RWH infrastructure. This analysis was conducted under Mediterranean climatic conditions, characterized by frequent dry long periods and intense rain events that can involve more than $50 \%$ of the annual precipitation. These rain peaks allow an increase in the water supply together with the building height. However, in Spain there are three other climatic regions with different rainfall patterns. For instance, Murcia is a Semi-arid region, Madrid is Continental and Santiago de Compostela has an Atlantic climate with intense precipitations. Applying the same tank size $\left(25 \mathrm{~m}^{3}\right)$, the demand met in these areas under the same building conditions was different (see Online Resource 4). RWH was able to supply at least 50\% of the demand in Santiago de Compostela - $89 \%$ in the case of B strategies -, whereas in Murcia a redesign of the tank was needed, because it provided a maximum of $30 \%$. From this perspective, an in-depth analysis should determine the most eco-efficient strategies and designs depending on local conditions and environmental costs. 
Regionalization might also alter the benefits of RWH with respect to conventional supply systems. In this sense, treatment technologies might be different depending on the type of city, location, climate and water availability. For example, the benefits of RWH in Murcia might be higher than in other areas, because droughts increase the need for desalination plants, which are more energy intensive than other conventional treatment plants (Stokes and Horvath 2006). Thus, future studies should assess the feasibility of RWH considering the water treatment associated with each climatic region. In addition, the effects of implementing RWH at urban scale are greater, because smaller distribution pipes might be needed to supplement rainwater, and there is a reduction in the stormwater runoff and flooding events. In this case, an analysis at neighborhood scale might shed light on the net benefits of RWH.

\section{Conclusions}

In this paper, the best strategies for meeting the rainwater demand for laundry in a building were assessed from an environmental standpoint. Results indicate that a roof tank is in all the examined cases less environmentally detrimental than an underground tank. For instance, for a 15 -story building with harvested water distribution to all the apartments, the reductions in impacts due to tank location range from $61 \%$ to $89 \%$, depending on the impact category. A roof tank location enhances energy and material savings and most likely contributes to more energy-efficient buildings because the water in the tank may act as a thermal insulator. Further studies should address this issue to determine indirect benefits of RWH.

The distribution strategy chosen was found to be the most important factor in the optimization of RWH infrastructures. Within the roof tank scenarios, a distribution strategy that concentrates demand in the ground floor, enabling water to flow by gravity to the washing machines, was the environmentally optimal option resulting in impact reductions from $25 \%$ to $54 \%$ depending on the building height.

This laundry strategy that concentrates all demand in a laundry room is well known in the service sector, being currently used worldwide in penal institutions, hotels, university campuses and nursing homes. However, it has never been a widespread practice in residential buildings of developed Mediterranean countries, which are highly waterdemanding due to their easy access to potable water and which, simultaneously, suffer from frequent water shortages. Therefore, a behavioral change on demand should be promoted to a more sustainable and environmentally conscious society that optimizes resources and reduces its footprint. 
Additionally, the effects of regional features on the actual feasibility of RWH (i.e., rainfall patterns and water supply) should be thoroughly analyzed. First, the differences in rainfall patterns result in more or less rainwater harvested that meets the laundry demand. As a result, the tank sizing will be different given a constant demand and the environmental impacts will vary. Second, depending on the water scarcity, the net benefits of RWH might also change according to the water treatment technologies used in the area. In this case, a Semi-arid region might benefit from a smaller tank and the net benefit might be high because of the substitution of desalination plants. Future studies should address these issues more thoroughly and extend the assessment at the neighborhood scale. This analysis did not include waterrelated indicators because of the nature of the assessment (i.e., construction and operation of RWH at a building scale). However, when comparing to conventional water supply, additional water indicators such as the water footprint could provide more information about the suitability of each system in the context of the water cycle.

\section{ACKNOWLEDGMENTS}

The authors are grateful for the financial support of the Spanish Ministry of Science and Innovation of Spain (MICINN) within the project 'Análisis ambiental del aprovechamiento de las aguas pluviales urbanas' (Ref. CTM2010-17365). The authors also wish to thank the Catalan government for the scholarship enjoyed by S. Angrill and the Spanish Ministry of Education for the grant awarded to A. Petit-Boix (FPU13/01273).

\section{REFERENCES}

Abdulla FA, Al-Shareef AW (2009) Roof rainwater harvesting systems for household water supply in Jordan. Desalination 243:195-207.

AEMET. Spanish National Meteorological Agency (2013) Standard Climate Values. http://www.aemet.es/en/serviciosclimaticos/datosclimatologicos/valoresclimatologicosAccessed November 2013.

Angrill S, Farreny R, Gasol CM, et al (2012) Environmental analysis of rainwater harvesting infrastructures in diffuse and compact urban models of Mediterranean climate. Int J Life Cycle Assess 17:25-42. doi: 10.1007/s11367011-0330-6

Bronchi V, Jolliet O (2002) Life cycle assessment of rainwater use for domestic needs. Inst soil water Manag 1-10.

Commission Regulation (EU) No 1015/2010 of 10 November 2010 implementing Directive 2009/125/EC of the 
European Parliament and of the Council with regard to ecodesign requirements for household washing machines. Available at http://eur-lex.europa.eu/LexUri.

Coombes PJ, Kuczera G, Kalma JD, Argue JR (2002) An evaluation of the benefits of source control measures at the regional scale. Urban Water 4:307-320. doi: 10.1016/S1462-0758(02)00028-6

CYPE Ingenieros S.A. (2011) CYPE ingenieros, Software for Architecture, Engineering \& Construction. http://www.cype.es/. v. 2011.

Devkota J, Schlachter H, Apul D (2015a) Life Cycle Based Evaluation of Harvested Rainwater Use in Toilets and for Irrigation. J Clean Prod. doi: 10.1016/j.jclepro.2015.02.021

Devkota JP, Burian SJ, Tavakol-Davani H, Apul DS (2015b) Introducing Demand to Supply Ratio as a New Metric for Understanding Life Cycle Greenhouse Gas (GHG) Emissions from Rainwater Harvesting Systems. J Clean Prod. doi: 10.1016/j.jclepro.2015.10.073

di Castri F, Mooney H (1973) Mediterranean Type Ecosystems - Origin and Structure | Springer.

Domènech L, Saurí D (2011) A comparative appraisal of the use of rainwater harvesting in single and multi-family buildings of the Metropolitan Area of Barcelona (Spain): social experience, drinking water savings and economic costs. J Clean Prod 19:598-608. doi: 10.1016/j.jclepro.2010.11.010

Elzen B, Geels F, Green K (2004) System Innovation and the Transition to Sustainability: Theory, Evidence and Policy. Edward Elgar Publishing, Inc, Northampton

EN 15804:2011 (2011) Sustainability of construction works - Environmental product declarations - Core rules for the product category of construction works. European Standard.

Farreny R, Gabarrell X, Rieradevall J (2011a) Cost-efficiency of rainwater harvesting strategies in dense Mediterranean neighbourhoods. Resour Conserv Recycl 55:686-694. doi: 10.1016/j.resconrec.2011.01.008

Farreny R, Morales-Pinzón T, Guisasola A, et al (2011b) Roof selection for rainwater harvesting: Quantity and quality assessments in Spain. Water Res 45:3245-3254. doi: 10.1016/j.watres.2011.03.036

Fletcher TD, Deletic A, Mitchell VG, Hatt BE (2008) Reuse of urban runoff in Australia: a review of recent advances and remaining challenges. J Environ Qual 37:S116-27. doi: 10.2134/jeq2007.0411

Frischknecht R, Jungbluth N, Althaus H-J, et al (2005) The ecoinvent database: Overview and methodological 
framework. Int J Life Cycle Assess 10:3-9.

Ghisi E, Bressan DL, Martini M (2007) Rainwater tank capacity and potential for potable water savings by using rainwater in the residential sector of southeastern Brazil. Build Environ 42:1654-1666. doi: 10.1016/j.buildenv.2006.02.007

Glendenning CJ, Vervoort RW (2011) Hydrological impacts of rainwater harvesting (RWH) in a case study catchment: The Arvari River, Rajasthan, India. Part 2. Catchment-scale impacts. Agric Water Manag 98:715730. doi: 10.1016/j.agwat.2010.11.010

Grant T, Hallmann M (2003) Urban Domestic Water Tanks : Life Cycle Assessment. Water 22-27.

Guinée JB, Gorrée M, Heijungs R, Huppes G, Kleijn R, Koning A de, Oers L van, Wegener Sleeswijk A, Suh S, Udo de Haes HA, Bruijn H de, Duin R van HM (2002) Handbook on life cycle assessment. Operational guide to the ISO standards. I: LCA in perspective. IIa: Guide. IIb: Operational annex. III: Scientific background. Kluwer Academic Publishers, ISBN 1-4020-0228-9, Dordrecht, 692 pp.

Herrmann T, Schmida U (2000) Rainwater utilisation in Germany: efficiency, dimensioning, hydraulic and environmental aspects. Urban Water 1:307-316.

Herz RK, Lipkow A (2002) Life cycle assessment of water mains and sewers. Water Sci Technol Water Supply 2:5158.

Hischier R, Weidema B, Althaus H, et al (2010) Implementation of Life Cycle Impact Assessment Methods. Final report ecoinvent v2.2 No. 3 .

ISO (2006) ISO 14040: 2006 Environmental management - Life cycle assessment - Principles and framework.

Jones MP, Hunt WF (2010) Performance of rainwater harvesting systems in the southeastern United States. Resour Conserv Recycl 54:623-629. doi: 10.1016/j.resconrec.2009.11.002

Lassaux S, Renzoni R, Germain A (2007) Life Cycle Assessment of Water: from the Pumping Station to the Wastewater Treatment Plant. Int J 12:118-126.

Leggett D, Brown R, Brewer D, et al (2001) Rainwater and greywater use in buildings: best practice guidance.

Lemos D, Dias AC, Gabarrell X, Arroja L (2013) Environmental assessment of an urban water system. J Clean Prod 54:157-165. doi: 10.1016/j.jclepro.2013.04.029 
Lundie S, Peters GM, Beavis PC (2004) Life cycle assessment for sustainable metropolitan water systems planning. Environ Sci Technol 38:3465-3473. doi: 10.1021/es034206m

Lye DJ (2009) Rooftop runoff as a source of contamination: A review. Sci. Total Environ. 407:5429-5434.

Meng L, Forberg A (2007) 3D building generalization. In: Mackaness W, Ruas A, Sarjakoski T (ed) Challenges in the Portrayal of Geographic Information. Elsevier Science, Amsterdam, pp 211-232

MetaBase ITeC (2010) Online ITeC database: prices, technical details, companies, certificates, product pictures and environmental data. http://www.itec.cat/metabase. Accessed February 2013.

Morales-Pinzón T, Lurueña R, Rieradevall J, et al (2012a) Financial feasibility and environmental analysis of potential rainwater harvesting systems: A case study in Spain. Resour Conserv Recycl 69:130-140. doi: 10.1016/j.resconrec.2012.09.014

Morales-Pinzón T, Rieradevall J, Gasol C, Gabarrell X (2012b) Plugrisost® v1.0. Dynamic water flow model for domestic use, with emphasis on use of unconventional sources (rainwater, greywater).

Mwenge Kahinda J, Taigbenu AE (2011) Rainwater harvesting in South Africa: Challenges and opportunities. Phys. Chem. Earth, Parts A/B/C 36:968-976.

Ngigi SN (2003) What is the limit of up-scaling rainwater harvesting in a river basin? Phys Chem Earth 28:943-956. doi: 10.1016/j.pce.2003.08.015

Nolde E (2007) Possibilities of rainwater utilisation in densely populated areas including precipitation runoffs from traffic surfaces. Desalination 215:1-11. doi: 10.1016/j.desal.2006.10.033

Oliver-Solà J, Josa A, Arena AP, et al (2011) The GWP-Chart: An environmental tool for guiding urban planning processes. Application to concrete sidewalks. Cities 28:245-250. doi: 10.1016/j.cities.2011.01.003

Pandey DN, Gupta AK, Anderson DM (2003) Rainwater harvesting as an adaptation to climate change. Curr. Sci. $85: 46-59$.

Petit-Boix A, Roigé N, de la Fuente A, et al (2016) Integrated Structural Analysis and Life Cycle Assessment of Equivalent Trench-Pipe Systems for Sewerage. Water Resour Manag 30:1117-1130. doi: 10.1007/s11269-015$1214-5$

Petit-Boix A, Sanjuan-Delmás D, Chenel S, et al (2015) Assessing the energetic and environmental impacts of the 
operation and maintenance of Spanish sewer networks from a life-cycle perspective. Water Resour Manag 29:2581-2597. doi: 10.1007/s11269-015-0958-2

Petit-Boix A, Sanjuan-Delmás D, Gasol C, et al (2014) Environmental Assessment of Sewer Construction in Small to Medium Sized Cities Using Life Cycle Assessment. Water Resour Manag 28:979-997. doi: 10.1007/s11269014-0528-Z

PRé Consultants (2010) SimaPro 7.2.0. PRé Consultants, Amersfoort.

Public Utilities Board of Singapore (PUB) (2012) Collecting Every Drop of Rain. http://www.pub.gov.sg/LongTermWaterPlans/wfall.html. Accessed on 09/01/2012.

Rahman A, Dbais J, Imteaz M (2010) Sustainability of Rainwater Harvesting Systems in Multistorey Residential Buildings. Am J Eng Appl Sci 3:73-82. doi: 10.3844/ajeassp.2010.73.82

Reitano R (2011) Water harvesting and water collection systems in Mediterranean area. the case of Malta. In: Procedia Engineering. pp 81-88

Riesenberger J, Koeller J (2005) Commercial Laundry $\quad$ Facilities. http://www.allianceforwaterefficiency.org/WorkArea/linkit.aspx?LinkIdentifier=id\&ItemID=802.

Roebuck R, Oltean-Dumbrava C, Tait S (2010) Whole life cost performance of domestic rainwater harvesting systems in the United Kingdom. Water Environ. J. no-no.

Saurí D (2003) Lights and Shadows of Urban Water Demand Management: The Case of the Metropolitan Region of Barcelona. Eur. Plan. Stud. 11:229-243.

Sazakli E, Alexopoulos A, Leotsinidis M (2007) Rainwater harvesting, quality assessment and utilization in Kefalonia Island, Greece. Water Res 41:2039-2047. doi: 10.1016/j.watres.2007.01.037

Stokes J, Horvath A (2006) Life Cycle Energy Assessment of Alternative Water Supply Systems (9 pp). Int J Life Cycle Assess 11:335-343. doi: 10.1065/lca2005.06.214

van Roon M (2007) Water localisation and reclamation: Steps towards low impact urban design and development. J Environ Manage 83:437-447. doi: 10.1016/j.jenvman.2006.04.008

Vargas-Parra MV, Villalba G, Gabarrell X (2013) Applying exergy analysis to rainwater harvesting systems to assess resource. Resour Conserv Recycl 72:50-59. 
Venkatesh G, Hammervold J, Brattebø H (2009) Combined MFA-LCA for Analysis of Wastewater Pipeline Networks. J Ind Ecol 13:532-550. doi: 10.1111/j.1530-9290.2009.00143.x

Villarreal EL, Dixon A (2005) Analysis of a rainwater collection system for domestic water supply in Ringdansen, Norrköping, Sweden. Build Environ 40:1174-1184. doi: 10.1016/j.buildenv.2004.10.018

Ward S, Memon FA, Butler D (2010) Harvested rainwater quality: The importance of appropriate design. Water Sci Technol 61:1707-1714. doi: 10.2166/wst.2010.102

Zhang Y, Chen D, Chen L, Ashbolt S (2009) Potential for rainwater use in high-rise buildings in Australian cities. J Environ Manage 91:222-226. doi: 10.1016/j.jenvman.2009.08.008

Zhu K, Zhang L, Hart W, et al (2004) Quality issues in harvested rainwater in arid and semi-arid Loess Plateau of northern China. J Arid Environ 57:487-505. doi: 10.1016/S0140-1963(03)00118-6 


\section{FIGURE CAPTIONS}

Fig1 Front view of the three distribution strategies proposed for the roof (R) and underground (U) tank scenarios represented on the fifteen-story-building structure: A (laundry room), B (nearest floors) and C (all building)

Fig2 Impact assessment comparison of underground-tank scenarios (U) for each building height $(6,9,12$ and 15 floors) and distribution strategy (A-laundry room; B-nearest floors; C-all building

Fig3 Impact assessment comparison of roof-tank scenarios (R) for each building height (6, 9, 12 and 15 floors) and distribution strategy (A-laundry room; B-nearest floors; C-all building)

Fig4 Impact assessment comparison of the underground-tank scenarios (AU) and the roof-tank scenarios (CR) for each building height and impact category

\section{TABLE CAPTIONS}

Table 1 Inventory data of stages (catchment, storage and distribution) and supply and demand characteristics for the roof $(\mathrm{R})$ and underground $(\mathrm{U})$ tank scenarios and for each building height

Table 2 Impact contribution of all stages within each building height for each distribution strategy and tank location (R- roof and U-underground tank) according to the GWP category 
Table 1 Inventory data of stages (catchment, storage and distribution) and supply and demand characteristics for the roof $(\mathrm{R})$ and underground $(\mathrm{U})$ tank scenarios and for each building height

\begin{tabular}{|c|c|c|c|c|c|c|c|c|c|c|}
\hline & \multicolumn{4}{|c|}{ ROOF TANK (R) } & \multicolumn{4}{|c|}{ UNDERGROUND TANK (U) } \\
\hline & \multicolumn{2}{|c|}{ Data per building } & $\begin{array}{c}6 \\
\text { floors }\end{array}$ & $\begin{array}{c}9 \\
\text { floors }\end{array}$ & \begin{tabular}{|c|}
12 \\
floors
\end{tabular} & $\begin{array}{c}15 \\
\text { floors }\end{array}$ & $\begin{array}{c}6 \\
\text { floors }\end{array}$ & $\begin{array}{c}9 \\
\text { floors }\end{array}$ & $\begin{array}{c}12 \\
\text { floors }\end{array}$ & $\begin{array}{c}15 \\
\text { floors }\end{array}$ \\
\hline \multirow{2}{*}{ CATCHMENT } & \multicolumn{2}{|l|}{ Gutter (m) } & 0 & 0 & 0 & 0 & 63 & 63 & 63 & 63 \\
\hline & \multicolumn{2}{|c|}{ Downpipe (m) } & 0 & 0 & 0 & 0 & 23 & 31 & 39 & 48 \\
\hline STORAGE & \multicolumn{2}{|c|}{ Tank volume $\left(\mathrm{m}^{3}\right)$} & 25 & 25 & 25 & 25 & 25 & 25 & 25 & 25 \\
\hline \multirow{4}{*}{ DISTRIBUTION } & \multirow{3}{*}{$\begin{array}{l}\text { Distribution } \\
\text { pipes (m) }\end{array}$} & $\begin{array}{l}\mathbf{A} \\
\text { (Laundry } \\
\text { room) }\end{array}$ & 26 & 34 & 42 & 51 & 18 & 18 & 18 & 18 \\
\hline & & \begin{tabular}{|l|} 
B \\
(Nearest \\
floors) \\
\end{tabular} & 211 & 211 & 211 & 211 & 222 & 222 & 222 & 222 \\
\hline & & $\begin{array}{l}\text { C (All } \\
\text { building) }\end{array}$ & 264 & 422 & 580 & 738 & 274 & 432 & 590 & 749 \\
\hline & \multicolumn{2}{|c|}{ Pump (items) } & 0 & 0 & 0 & 0 & 1 & 1 & 1 & 1 \\
\hline $\begin{array}{l}\text { Apartments per } \\
\text { building }\end{array}$ & \multicolumn{2}{|c|}{$\begin{array}{l}\text { Number of apartments } \\
\text { per building }\end{array}$} & 30 & 48 & 66 & 84 & 30 & 48 & 66 & 84 \\
\hline \multirow{2}{*}{$\begin{array}{l}\text { Water demand per } \\
\text { building }\end{array}$} & \multicolumn{2}{|l|}{ A and $C$} & 465 & 744 & 1,023 & 1,302 & 465 & 744 & 1,023 & 1,302 \\
\hline & \multicolumn{2}{|l|}{ B } & \multicolumn{8}{|c|}{372} \\
\hline \multirow{2}{*}{ Total water supply } & \multirow{2}{*}{\begin{tabular}{|l} 
Water \\
supplied \\
per year \\
and \\
building \\
$\left(\mathrm{m}^{3}\right)$ \\
\end{tabular}} & $A$ and $C$ & 279 & 320 & 338 & 339 & 279 & 320 & 338 & 339 \\
\hline & & B & 260 & 260 & 260 & 260 & 260 & 260 & 260 & 260 \\
\hline \multirow{2}{*}{ Demand satisfied } & \multirow{2}{*}{$\begin{array}{l}\text { Demand } \\
\text { satisfied } \\
\text { per } \\
\text { building } \\
(\%)\end{array}$} & $A$ and $C$ & 60 & 43 & 33 & 26 & 60 & 43 & 33 & 26 \\
\hline & & B & 70 & 70 & 70 & 70 & 70 & 70 & 70 & 70 \\
\hline
\end{tabular}


Table 2 Impact contribution of all stages within each building height for each distribution strategy and tank location (R- roof and U-underground tank) according to the GWP category

\begin{tabular}{|c|c|c|c|c|c|c|c|}
\hline \multirow{2}{*}{\multicolumn{2}{|c|}{$\begin{array}{rr}\text { Distribution } \\
\text { strategy }\end{array}$}} & \multicolumn{2}{|c|}{ A. Laundry room } & \multicolumn{2}{|c|}{ B. Nearest floors } & \multicolumn{2}{|c|}{ C. All Building } \\
\hline & & \multirow{2}{*}{$\frac{\mathbf{R}}{0.0}$} & \multirow{2}{*}{$\frac{\mathbf{U}}{19.6}$} & \multirow{2}{*}{$\frac{\mathbf{R}}{0.0}$} & \multirow{2}{*}{$\frac{\mathbf{U}}{12.9}$} & \multirow{2}{*}{$\begin{array}{c}\mathbf{R} \\
0.0\end{array}$} & \multirow{2}{*}{$\begin{array}{c}\mathbf{U} \\
11.6\end{array}$} \\
\hline$\tilde{\alpha}$ & HARVESTING (\%) & & & & & & \\
\hline 0 & STORAGE (\%) & 96.9 & 73.1 & 79.8 & 48.1 & 75.9 & 43.2 \\
\hline بـ & DISTRIBUTION $(\%)$ & 3.1 & 7.3 & 20.2 & 39.0 & 24.1 & 45.2 \\
\hline $\overrightarrow{6}$ & \begin{tabular}{|l} 
Total absolute value ( $\mathrm{kg} \mathrm{CO}_{2}$ eq.) \\
\end{tabular} & $3.0 \mathrm{E}-01$ & 4.7E-01 & $4.0 \mathrm{E}-01$ & $7.6 \mathrm{E}-01$ & $3.9 \mathrm{E}-01$ & $7.9 \mathrm{E}-01$ \\
\hline \multirow{4}{*}{ 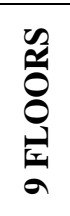 } & HARVESTING (\%) & 0.0 & 18.4 & 0.0 & 13.3 & 0.0 & 7.9 \\
\hline & STORAGE (\%) & 96.4 & 66.6 & 81.5 & 47.9 & 68.8 & 28.6 \\
\hline & DISTRIBUTION $(\%)$ & 3.6 & 15.0 & 18.5 & 38.8 & 31.2 & 63.5 \\
\hline & Total absolute value (kg $\mathrm{CO}_{2}$ eq.) & $3.0 \mathrm{E}-01$ & $4.5 \mathrm{E}-01$ & 4.4E-01 & 7.6E-01 & 4.2E-01 & $1.0 \mathrm{E}+00$ \\
\hline \multirow{4}{*}{  } & HARVESTING (\%) & 0.0 & 18.1 & 0.0 & 13.6 & 0.0 & 5.7 \\
\hline & \begin{tabular}{|l|} 
STORAGE (\%) \\
\end{tabular} & 95.7 & 63.6 & 81.9 & 47.7 & 62.2 & 20.0 \\
\hline & DISTRIBUTION $(\%)$ & 4.3 & 18.3 & 18.1 & 38.7 & 37.8 & 74.3 \\
\hline & Total absolute value (kg $\mathrm{CO}_{2}$ eq.) & $3.0 \mathrm{E}-01$ & $4.5 \mathrm{E}-01$ & 4.4E-01 & 7.7E-01 & 4.6E-01 & $1.4 \mathrm{E}+00$ \\
\hline \multirow{4}{*}{ 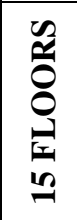 } & HARVESTING (\%) & 0.0 & 18.1 & 0.0 & 14.0 & 0.0 & 4.3 \\
\hline & STORAGE (\%) & 94.4 & 61.5 & 80.2 & 47.5 & 53.7 & 14.7 \\
\hline & DISTRIBUTION $(\%)$ & 5.6 & 20.4 & 19.8 & 38.5 & 46.3 & 81.0 \\
\hline & Total absolute value (kg $\mathrm{CO}_{2}$ eq.) & $2.7 \mathrm{E}-01$ & $4.6 \mathrm{E}-01$ & 4.1E-01 & 7.7E-01 & 4.7E-01 & $1.9 \mathrm{E}+00$ \\
\hline
\end{tabular}


A

Laundry room

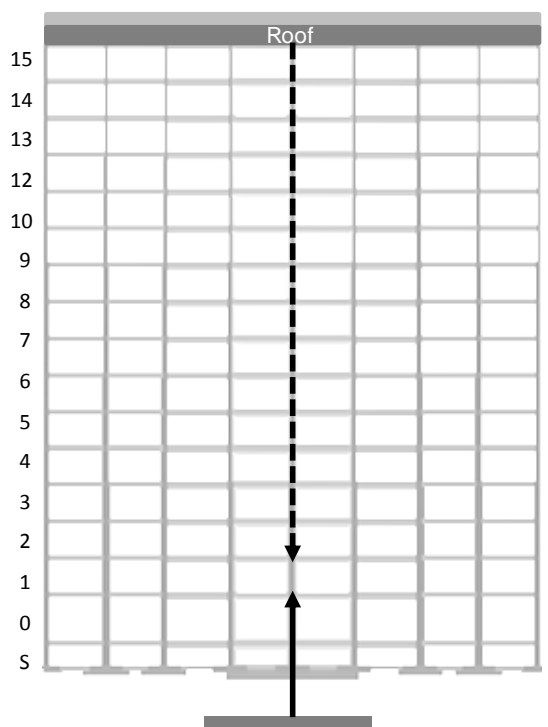

Underground
B

Nearest floors



Underground
C

All building

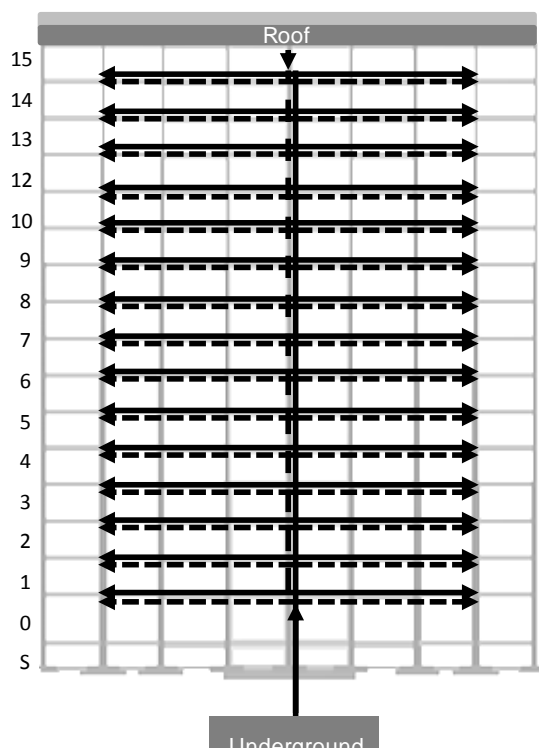

Underground

Catchment

Storage

Distribution

Fig1 Front view of the three distribution strategies proposed for the roof $(\mathrm{R})$ and underground (U) tank scenarios represented on the fifteen-story-building structure: A (laundry room), B (nearest floors) and C (all building) 


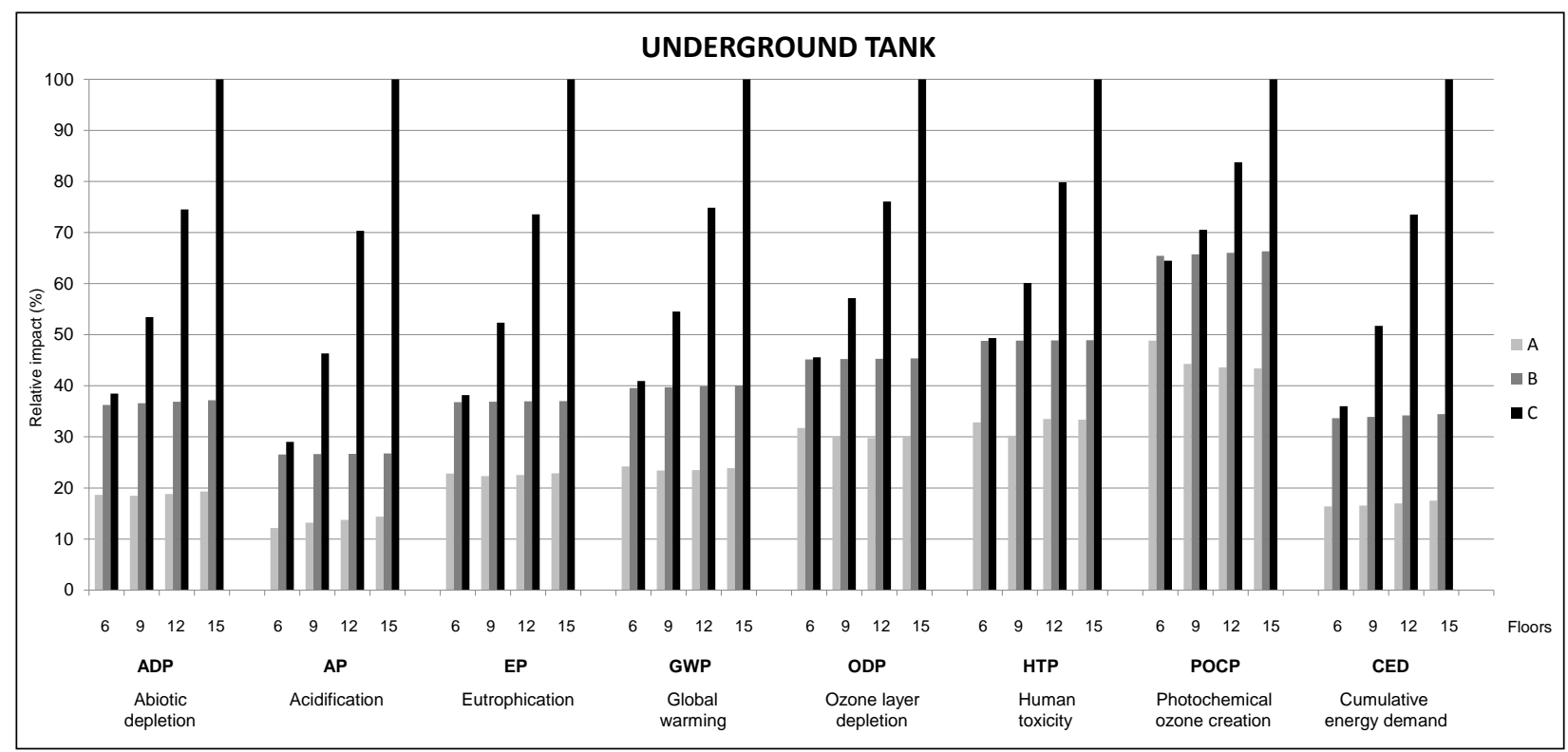

Fig2 Impact assessment comparison of underground tank scenarios (U) for each building height (6, 9, 12 and 15 floors) and distribution strategy (A-laundry room; B-nearest floors; C-all building) 


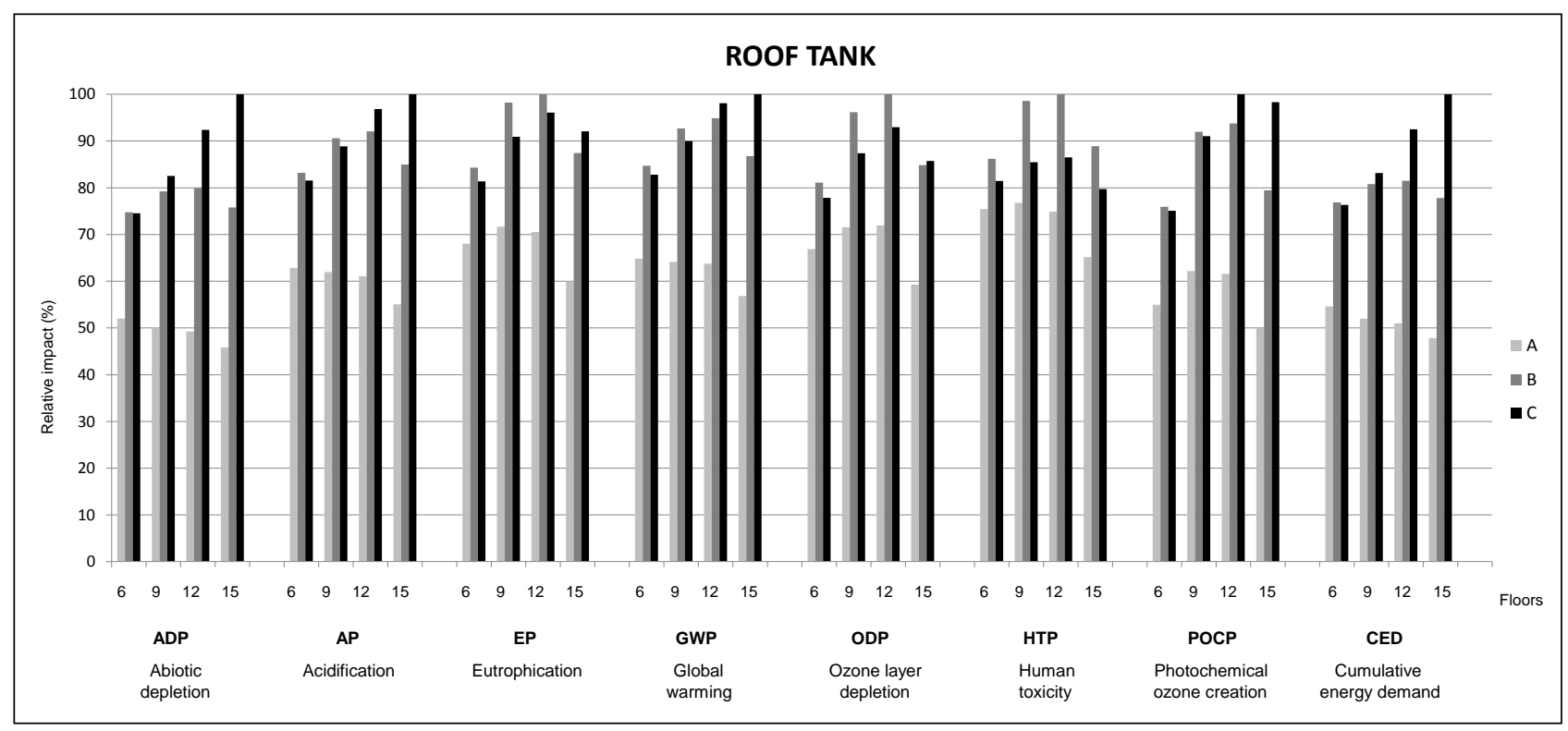

Fig3 Impact assessment comparison of roof tank scenarios $(\mathrm{R})$ for each building height $(6,9,12$ and 15 floors) and distribution strategy (A-laundry room; B-nearest floors; C-all building) 

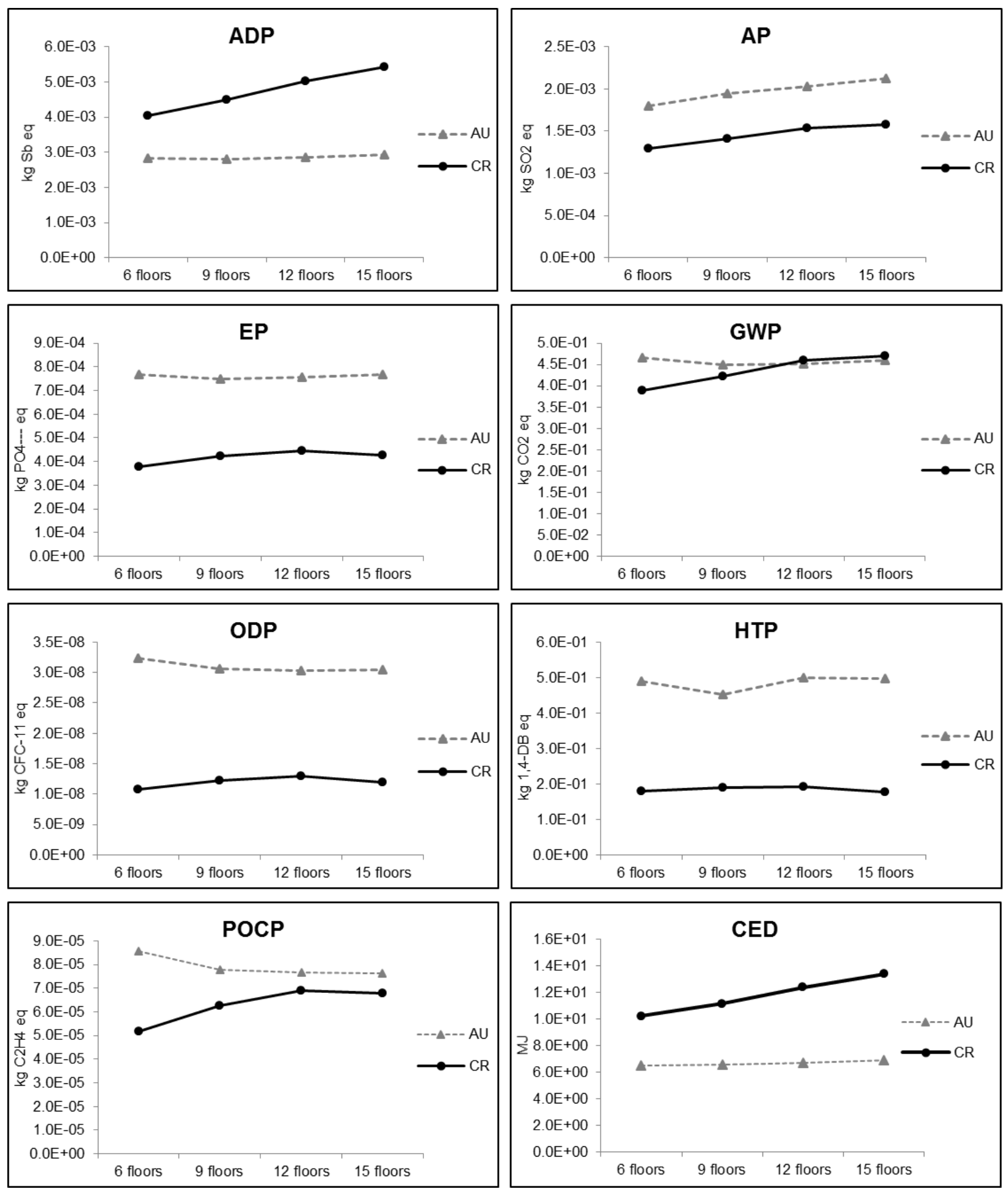

Fig4 Impact assessment comparison of the underground-tank scenarios (AU) and the roof-tank scenarios (CR) for each building height and impact category 